\title{
The relationship between menopausal status and different histopathological pictures among 300 Indonesian females with breast cancer
}

Esti Soetrisno*, Gunawan Tjahjadi*, Goi Sakamoto^, Endang Sri Roostini*, Santoso Cornain*, Didid Tjindarbumi $\sim$, Muchlis Ramli $\sim$, Idral Darwis $\sim$, Joedo Prihartono\$, Yoshiyuki Ohno", Setyawati Budiningsih ${ }^{\S}$ Kenji Wakai^

\begin{abstract}
Abstrak
Penelitian epidemiologik dengan cara kasus-kontrol pada 300 wanita Indonesia dengan kanker payudara yang mengunjungi Rumah Sakit Dr. Cipto Mangunkusumo, Jakarta dilakukan pada tahun 1989-1991. Ditemukan beberapa variasi gambaran histopatologik sebagai berikut: karsinoma duktus invasif(KDI) pada sebagian besar, yaitu pada 265 kasus (88.33\%). Di antara KDI terdapat 147 kasus (49\%) jenis skirus, 179 jenis padat tubuler, 39 kasus (13\%) jenis papilotubuler; karsinoma moduler pada 17 kasus (5.68\%), karsinoma invasif lobuler pada 7 kasus (2.33\%), karsinoma duktal insitu dan karsinoma mukosa pada 4 kasus (1.33\%). Penyakit Paget ditemukan pada 2 kasus $(0.67 \%)$ dan karsinoma adenoidkistik pada 1 kasus (0.33\%). Status menopause telah diketahui sebagai salah satu faktor risiko terhadap perkembangan kanker payudara. Evaluasi terhadap pengaruh status menopause terhadap gambaran histopatologik memberikan hasil positif pada kanker duktal invasif jenis tubuler padat.
\end{abstract}

Abstract

Case control epidemiological study of 300 Indonesian female with breast cancer from Dr. Cipto Mangunkusumo Hospital, Jakarta was done in 1989-1991. There were some variety of the histopathological pictures had been reported as follows: Scirrhous type of IDC (Invasive Ductal Carcinoma) 147 cases (49\%), Solidtubular type of IDC 179 cases (26,33\%), Papillotubular type of IDC 39 cases (I3\%); totals IDC 265 cases $(88,33 \%)$ the main variant of our cases. Other variety: Medullary carcinoma 17 cases $(5,68 \%)$, ILC (Invasive Lobular Carcinoma) 7 cases (2,33\%), DCIS (Ductal Carcinoma In Situ) and MC (Mucous Carcinoma) 4 cases (1.33\%) respectively, Paget's disease 2 cases $(0,67 \%)$ and ACC (Adenoid Cystic Carcinoma) was presented only in I case $(0,33 \%)$. Menopause Status was also documented as one of risk factors for the development of breast cancer. Evaluation on the influence of menopausal status to the histopathological pictures gave a positive result on the Solidtubular type of IDC.

Keywords: Breast cancer, menopausal status, histopathology

\section{INTRODUCTION}

Breast Cancer (BC) shows varied classifications based on the histogenesis, the histological and clinical pictures. The WHO classification was generally accepted to be used as a standard criteria on the Histological typing of the whole body tumor of human being. $1,2,3$ According to the WHO classification, BC were divided into 3 main groups, namely: 1). Non-invasive Carcinoma (Ductal Carcinoma In Situ and

* Department of Anatomic Pathology, Faculty of Medicine, University of Indonesia, Jakarta, Indonesia

\& Department of Community Medicine, Faculty of Medicine, University of Indonesia, Jakarta, Indonesia

Department of Surgery, Faculty of Medicine, University of Indonesia, Jakarta, Indonesia

* Department of Preventive Medicine, Nagoya University School of Medicine, Nagoya, Japan

^ Pathology Division Cancer Institute, Tokyo, Japan.
Lobular Carcinoma In Situ), 2). Invasive Carcinoma (there are 11 variants, inclusive Invasive Ductal Carcinoma, Invasive Lobular Carcinoma, Papillary Carcinoma and others/special type carcinoma as usually mentioned in some modification of BC Classification), and the very special one, 3). Paget's disease of the nipple.

On 1986 Japanese Breast Cancer Society found a significant differences clinical course of IDC, depend on the histopathological appearances; these 3 subtypes of IDC namely as: -Papillotubular IDC, -Solid-tubufar IDC and Scirrhous IDC. These 3 subtypes of IDC have 10 years survival rate: $77.4 \%, 64.9 \%$ and $61.2 \%$, respectively. 4

Multi risk factors on BC widely acceptable, and only one third being clarify by invitro/experimental studies or by epidemiological studies to improve the actual effect/relation of the endogenic and-or the exogenic breast carcinogen-cocarcinogen. The most po- 
pular risk factor on recent epidemiological studies briefly that nutritional and environment have a benefit role as a carcinogen-cocarcinogen. The conventional concepts such as genetic, hormonal status is still of great interest to be discussed.5-9 On biological behavior emerged a tendency that the histological pictures of BC-types-variant both by light microscope examination and immuno-enzymatic elaborative studies, determine a complex relationship which is still in doubt between the local-systemic/immunologic host reaction predominantly stimulate or inhibit-supress tumor growth-behaviour. ${ }^{10-15}$.

Some reports on Race-ethnic-geographic map in relation to specific organ cancer could be found easily, on the other hand there is only a few elaborative study on the relation of any specific histopathological BC type to the epidemiological study result on BC risk factors like the possibility race influences on medullary carcinoma of the breast that more frequently raised among the Black people, otherwise the Whitewomen have the highest responsibility suffer BC.5,7 Lobular carcinoma was ordinary well known has a responsibility on multifocal or a 'mirror image' on bilaterality growth. On this occasion will be presented our data analysis one of the risk factors: menopausal status on purpose has an influence to the histopathological picture of some variant of BC in our 300 cases.

\section{MATERIAL AND METHODS}

The first three years $(1989,1990,1991)$ of collaborative study of Triplet Case Control on Indonesian Female BC using 300 cases of $\mathrm{BC}$ and 2 pairs control population at Dr. Cipto Mangunkusumo Hospital, Jakarta.

Based on Tjahjadi et.al., 18 the outcome of 300 cases of $\mathrm{BC}$, as follow: -Noninvasive ductal carcinoma (DCIS) 4 cases (1,33\%), -Invasive ductal carcinoma (IDC) 265 cases $(88,33 \%)$, consisting of the 3 subtypes: Papillotubular IDC 39 cases (13\%), Solidtubular IDC 75 cases (26,33\%), Scirrhous IDC $147 \%$ cases (49\%), -Mucinous carcinoma (MC) 6 cases $(1,33 \%)$, -Medullary carcinoma 17 cases $(5,6 \%)$, -Invasive lobular carcinoma (ILC) 7 cases $(2,33 \%$ ), Adenoid cystic carcinoma (ACC) 1 case $(0,33 \%)$, and Paget's disease of the nipple 2 cases $(0,67 \%)$.

Setyawati et al 19 listed the $1 \%$ significant risk factors: Urbaner, young first sexual contact, trauma, obesity, late menarche, irregular cycle, coconut milk food, no vegetable daily consumptive; and as significant at 5\%: Menopause Status and fatty diet.

On Table 1 we used the WHO Classification to look the over all view of $\mathrm{BC}$ types distribution versus the Menopause Status. And than we'll separate the composition of the major BC type IDC into 3-subtypes according to the Japanese Breast Cancer Society, 1986 , to be compared with the other, presented in Table 2 .

Table 1. Distribution on 300 Cases of Breast Cancer present in WHO Classification according to Menopausal Status

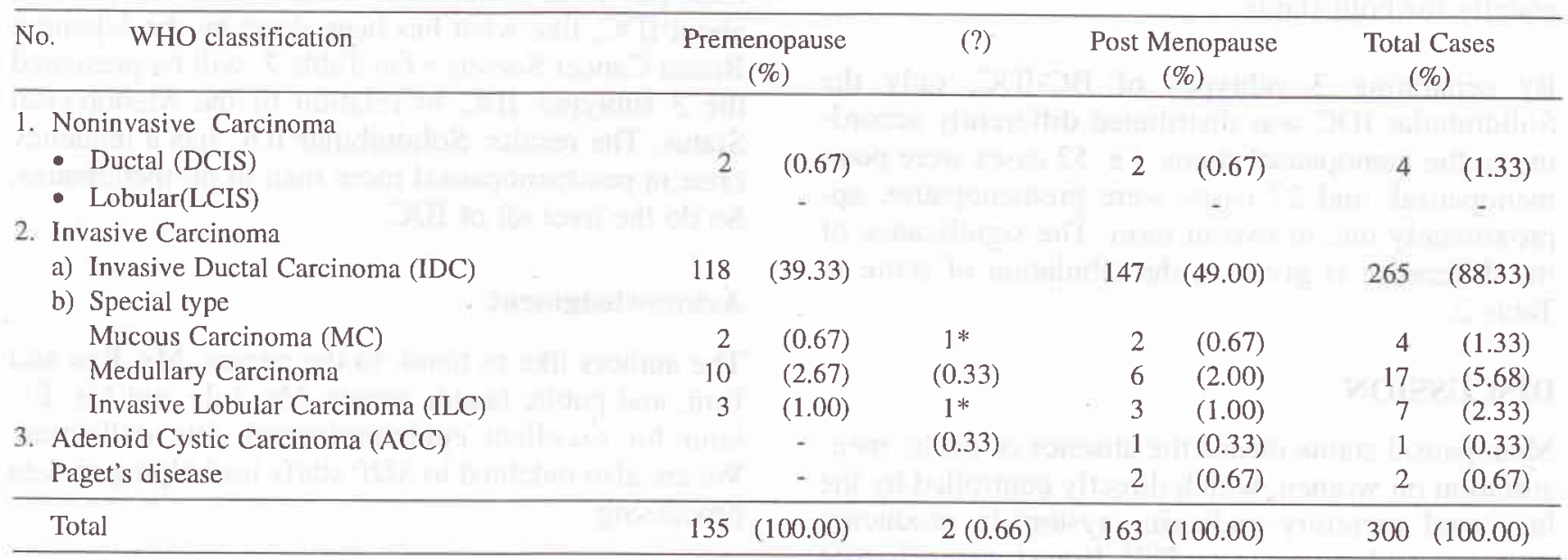

*) : Consideration on age incident, these two unknown menopause status on Table 1 most likely included to the postmenopause group 
Table 2. Distribution of the three subtypes of invasive ductal carcinoma (IDC) of the breast according to menopausal status

\begin{tabular}{lcccccc}
\hline Subtypes IDC & \multicolumn{2}{c}{$\begin{array}{c}\text { Premenopause } \\
(\%)\end{array}$} & \multicolumn{2}{c}{$\begin{array}{c}\text { Postmenopause } \\
(\%)\end{array}$} & \multicolumn{2}{c}{$\begin{array}{c}\text { Total Cases } \\
(\%)\end{array}$} \\
\hline Papilotubular IDC & 19 & $(7.17)$ & 20 & $(7.55)$ & 39 & $(14.72)$ \\
Solidtubular IDC & 27 & $(10.19)$ & 52 & $(19.62)$ & 79 & $(29.81)$ \\
Scirrhous IDC & 72 & $(27.17)$ & 75 & $(28.30)$ & 147 & $(55.47)$ \\
\hline \multicolumn{1}{c}{ Totals } & 118 & $(44.53)$ & 147 & $(55.47)$ & 265 & $(100.00)$ \\
\hline
\end{tabular}

Hopefully a significant result that there are some influences of the Menopause Status to some BC types. According to the common statement from the Indonesian Gynecologist, the average age Indonesian women get their Menopause Status at 45 years old.

A 'Grey Period' in women life is in the transitional state of Premenopause-Menopause-Postmenopause. Uncomfortable situation inclusive both physic/psychic could manifest in a great variety, personal dependency, and also raise I getting any kind of malignancy, especially the hormonal cyclic dependence tumors: Breast Cancer, Endometrial Cancer.20,21

\section{RESULTS}

Among 300 cases $\mathrm{BC}$ have been statistically analyzed, two patients with unknown menopausal status, 135 and 163 patients were premenopausal and postmenopausal, respectively. Histological typing showed that the major group IDC 265 cases. Among them 147 were postmenopause and 118 were premenopause; the other types were distributed almost equally for both status.

By separating 3 subtypes of BC-IDC, only the Solidtubular IDC was distributed differently according to the menopausal status; i.e. 52 cases were postmenopausal, and 27 cases were premenopause, approximately one-to two in ratio. The significance of the difference is given in the tabulation of score in Table 2.

\section{DISCUSSION}

Menopausal status means the absence of cyclic menstruation on women, which directly controlled by the hormonal secretory endocrine system in producing estrogen and progesteron.22,23 Breast parenchymes consist acinar and ductal epithelials similar as the endometrium, have ER- and Pgr- receptors, and on functional monthly has a good correlation with the ovulatory cycle. ${ }^{20-23}$ By the histological appearances, solidtubular IDC still has a characteristic of ductal formation beside the massive cellular population in dilated tubules/ductules, a moderate loss of polarity and differentiation predominantly accepted in entire the specimen. Mixed subtypes of IDC could be found in one $\mathrm{BC}$ case in equals, or sometimes maybe one type looks very dominant. Estimation on clinical course and prognosis considerate to the worst one. 4

Papillotubular IDC histologically has more delightful in cellular appearances, in controversial to the scirrhous IDC, which progressive in growth since formerly it becomes a malignant growth, without any demarcation-limitation of infiltrating activity, in a small strands formation, tubular/ductural configuration were very scanty. A high-grade malignancy, formerly to be specified as NOS (No Other Specified $\mathrm{BC}, 4,11$ Why these variety clearly manifest on $\mathrm{BC}$ ? We need a Trial-Further study on identification tumor markers and some enzymatic influences on any type of $\mathrm{BC}$, a multi variable analysis on each risk factors have been explored which could to become a fundamental tools or parameter for clarify some differences behavior of the $\mathrm{BC}$ types.

Survival rate observation, has a modality on determine the clinical course of any types of $\mathrm{BC}$, but this activity in our Department, especially Department of Anatomic Pathology, still a hard work, because personal identification of the patients could changed due to the less knowledge in cancer itself or due to the cultural aspects, for example the paternalistic familial, making the actual severe diseases, etc. Since IDC has been always reported to be the first BC type, we must pay more attention to collect more information about IDC, like what has been done by the Japanese Breast Cancer Society. ${ }_{4}$ On Table 2, will be presented the 3 subtypes IDC in relation to the Menopausal Status. The results: Solidtubular IDC has a tendency raise in postmenopausal more than in premenopause; So do the over all of IDC.

\section{Acknowledgment}

The authors like to thank to the nurses, Ms. Ros and Emi, and public health nurses, Ms. July and Ms. Erlaini for excellent epidemiological data collection. We are also indebted to SDP staffs for helping in data processing.

This work was supported by the Ministry of Education, Science, Sports and Culture of Japanese Gov- 
ernment, Grants No. 01042007, 04042013 and 06042006; and was partially supported by the Indonesian Cancer Foundation. This collaborative study was a part of Special Cancer Research project in Monbusho International Scientific Research Program, with the approval of the Dean, Faculty of Medicine, University of Indonesia, No. 4383/PT02. H4.FK/E/88.

\section{REFERENCES}

1. Mc.Divitt RW, Steward FW, Berg JW. Tumors of the Breast: Atlas of tumor pathology $2^{\text {nd }}$ series. Washington: AFIP 1968.

2. Page DL, Anderson TJ. Diagnostic Histopathology of the Breast. Edinburg: Churchill Livingstones 1987.

3. International Histological Classification of Tumors: Histological typing of Breast Tumors. WHO 1981.

4. Japanese Breast Cancer Society. The General Rules for clinical and pathological recording of breast cancer. Jpn J Surg 1989; 19: 612-32.

5. Berg JW. Clinical Implications of Risk Factors for Breast Cancer. Cancer 1984; 1: 589-91 (supplement)

6. Gump FE. Premalignant Diseases of the Breast: Surgical Clinical North America 1984; 64: 1051-9.

7. Ohno Y. Methodology and Evaluation of Dietary Factors in Japan. Recent Progress in Research on Nutrition and Cancer, pp 11-20. Wiley-Liss 1990.

8. Claus EB, Risch N, Thomson WD, Carter D. Relation between Breast Histopathology and Family History of Breast Cancer. Cancer 1993; 71: 147-53

9. Hurliman J, Gebhard S, Gomez F. Estrogen receptor, progesteron receptor, pS2, ERD 5, HSP27 and cathepsin D in invasive ductal breast carcinoma. Histopathology 1993; 23: 239-48.

10. Tiwari RM. Staging and Prognostic Factors. J Oncol 1989; 1: 139-42.

11. Oostterhuis JW. Breast Cancer: Pathological Aspects. Advanced Postgraduate Course on Oncology. Jakarta 1993.
12. Workshop on Prognostic Indicators in Breast Cancer. Cancer 1993; 71: 2127-69.

13. Yoshimoto M, Sakamoto G, Ohashi Y. Time Depency of the Influence of Prognostic Factors on Relapse in Breast Cancer. Cancer 1993; 72: 2993-3001.

14. Visscher DW, Sarkar F, LoRusso P, Sakr W, Ottosen S, Crissman JD. Immunohistologic Evaluation of Invasion-associated Proteases in Breast Cancer. Modern Path 1993; 6: 302-6.

15. Roeslan B Su. The Inhibition of Retinyl Acetate on the Growth of mammary tumor in GR mice. Thesis. Dept. of Pathobiology, University of Indonesia Post Graduate Study Program, Jakarta 1994

16. Azzopardi JG, Ahmed A, Millis RR. Problem in Breast Pathology W.B.Saunders 1979.

17. Page DL. Prognosis and Breast Cancer. Recognition of lethal and favorable prognostic types. Am J Pathol 1991; 15(4): 334-49.

18. Tjahjadi G, Sakamoto G, Tjindarbumi D, Watanabe S, Prihartono J, Ohno Y, et al. Pathological Aspects of Breast Cancer in Indonesian Females, Emphasizing on the modified WHO classification. Med J Indones 1995; 4: 156-62.

19. Budiningsih S, Ohno Y, Prihartono J, Ramli M, Wakai K, Cornain S, et al. Epidemiological analysis of risk factors for breast cancer in Indonesian females. Med J Indones 1995; 4: 163-8.

20. Hsieh CC, Tricopoulos D, Katsouyanni K, Yuasa S. Age at menarche, age at menopause, height and obesity as risk factors of breast cancer: Association and interaction in an international case-control study. Int J Cancer 1990; 46: 796-800

21. Ewertz M, Duffy SW. Risk of breast cancer in relation to reproductive factors in Denmark. Br J Cancer 1988; 58: 99104.

22. Paffeinbarger Jr RS, Kampert JB, Chang H-G. Characteristics that predict risk breast cancer before and after the menopause. J Am Epidemiology 1980; 112: 258-68.

23. Henderson BE, Ross Rk, Judo HL, Krailo MD, Pike MC. Do regular ovulatory cycles increase breast cancer risk? Cancer 1985 ; 56:1206-8. 